\title{
ПРАВОВЫЕ ПРОБЛЕМЫ И ОСОБЕННОСТИ ВЗЫСКАНИЯ МОРАЛЬНОГО ВРЕДА ПО ЗАКОНОДАТЕЛЬСТВУ РФ
}

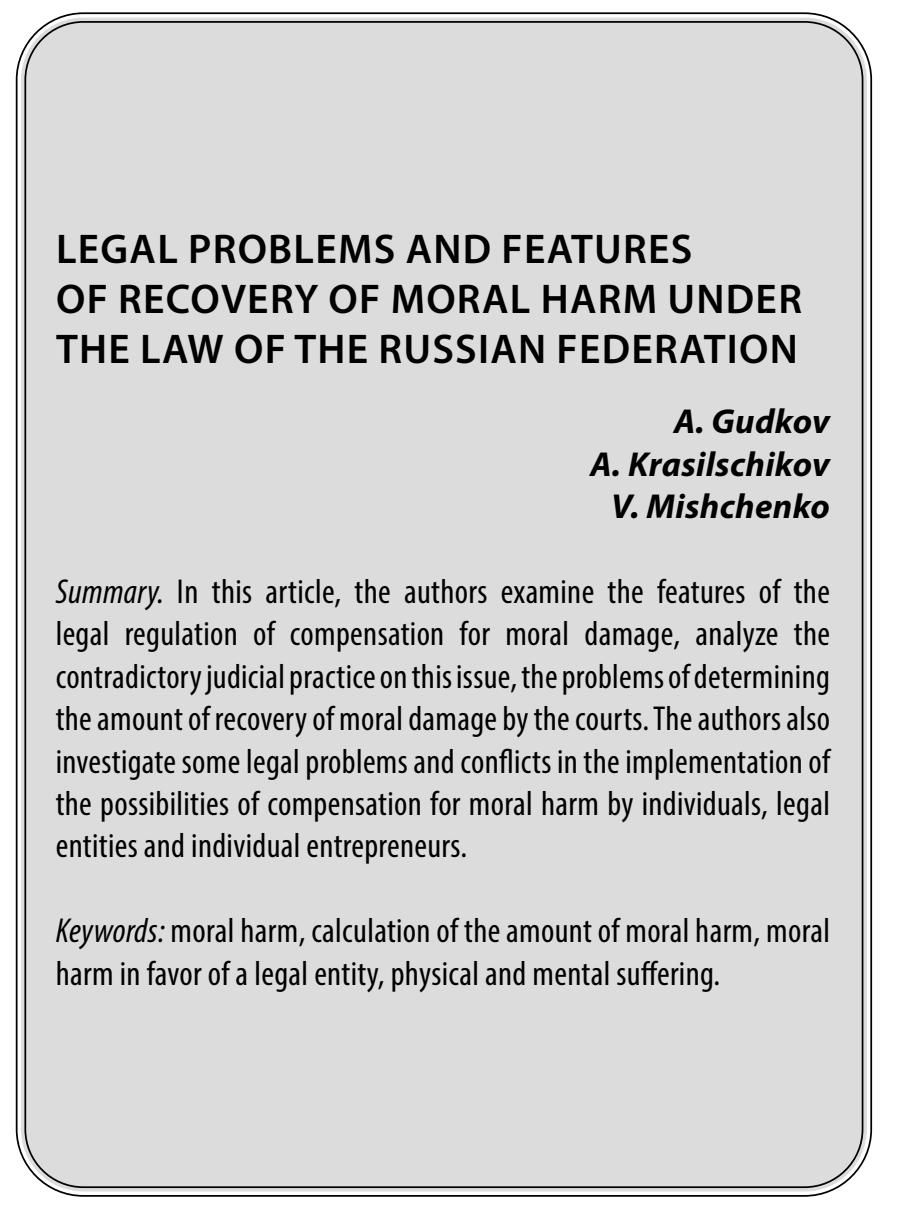

$\mathbf{K}$ омпенсация морального вреда возникла в юридической практике как законный способ защиты нравственного и душевного состояния человека, которому был причинен умышленно или по неосторожности материальный или нематериальный вред вследствие нарушения его конституционных прав или свобод, а также закона, предусматривающего взыскание компенсации. При этом важным условием при взыскании компенсации морального вреда является наличие неимущественного вреда - нравственного или морального страдания у пострадавшего лица либо материального ущерба.

С одной стороны, моральный вред исчисляется в материальном выражении, так как возмещение предусматривает именно денежную компенсацию, которую необходимо заранее рассчитать. Однако, законодатель до настоящего времени должным образом не разработал конкретную методику исчисления размера мораль-

\author{
Гудков Анатолий Иванович \\ К.ю.н., дочент, ВЮИ ФСИН России \\ gudkovaniv@yandex.ru \\ Красильщиков Анатолий Владимирович \\ К.ю.н., дочент, ВЮИ ФСИН России \\ krasilschikov@inbox.ru \\ Мищенко Вячеслав Иванович \\ К.ф.н., дочент, ВЮИ ФСИН России \\ vyacheslav-mischenko@mail.ru
}

Аннотация. В настоящей статье авторы рассматривают особенности правового регулирования компенсации морального вреда, анализируют противоречивую судебную практику по данному вопросу, проблемы определения сумм взыскания морального вреда судами. Авторы также исследуют некоторые правовые проблемы и коллизии в реализации возможностей возмещения морального вреда физическими, юридическими лицами и индивидуальными предпринимателями.

Ключевые слова: моральный вред, исчисление размера морального вреда, моральный вред в пользу юридического лица, физические и нравственные страдания.

ного вреда и не обеспечил прозрачность механизма защиты прав потерпевшего или пострадавшего в российском правовом поле. Поэтому большинство юристов и адвокатов сталкиваются с необходимостью изучения судебной практики по данному вопросу, дабы выиграть спор в суде о взыскании суммы компенсации морального вреда.

В данной статье мы рассмотрим вопросы исчисления размера морального вреда, исходя из законодательной базы, и отметим проблемы его взыскания, с которыми сталкиваются юристы на практике.

Для начала стоит выделить виды морального вреда. В частности, на практике принято компенсировать моральный вред, причиненный в результате имущественного вреда. Так, например, моральный вред взыскивается с виновного при ДТП, при постановке неправильного медицинского диагноза или неправильном 
лечении пациента, при затоплении квартиры, при незаконном изъятии (утере) имущества, при утрате трудоспособности гражданина, при незаконном лишении каких-либо конституционных прав. Также право на взыскание морального вреда имеют потребители, если им причинен имущественный вред. Таким образом, закон в данном случае связывает возможность получения моральной компенсации при условии возникновения прямого материального вреда.

При этом стоит отметить, что на компенсацию причиненного морального вреда могут претендовать как граждане, так и организации. Однако организации ограничены в основаниях для применения компенсации: законодатель предусмотрел возможность взыскания морального ущерба, причиненного юридическому лицу, исключительно в случае потери его деловой репутации. В частности, позиция Конституционного Суда Российской Федерации сформирована в 2003 году по делу № 508-О, которая заключалась в том, что взыскание морального вреда как способ защиты права присущ и юридическим лицам. С этой позицией можно согласиться, так как сложно представить, как возможно взыскать в пользу компании моральный вред, причиненный в результате утраты здоровья. Но тут же возникает и противоречивое восприятие, когда речь идет о взыскании морального вреда, причиненного вследствие причинения материального ущерба имуществу юридического лица. В этом случае непонятно, почему компания не имеет право на взыскание морального вреда.

Позиция законодателя изменилась в 2013 году с введением изменений в статью 152 ГК РФ, которая снова ограничила возможность юридических лиц взыскивать моральный вред, кроме случаев нарушения деловой репутации. Однако, в 2015 году Экономическая коллегия Верховного Суда Российской Федерации, рассмотрев спор по делу № 309-ЭС15-8331, отменила судебные акты предыдущих судебных инстанций, позволив взыскать моральный вред в пользу юридического лица. Таким образом, возникла правовая коллизия, при которой трактование статьи 152 ГК РФ о взыскании морального вреда получило два разных направления [2].

Также дискуссионным стал вопрос о взыскании суммы морального вреда в пользу индивидуального предпринимателя. Несмотря на то, что субъект предпринимательства является физическим лицом, многие юристы считают невозможным взыскание моральной компенсации в пользу ИП. В частности, такой позиции придерживался ВАС РФ в информационном письме № 46. В подтверждение данной позиции выступает и статья 33 АПК РФ, согласно которой в арбитражном суде не предусмотрен такой способ защиты права как взыскание морального вреда. Таким образом, автоматически споры между индивидуальными предпринимателями и юридическими лицами о взыскании компенсации за моральный вред становятся не допустимыми [5].

Моральный вред может взыскиваться как следствие причинения нематериального ущерба. В частности, это легко применяется при судебном споре по иску о защите чести и деловой репутации компании, которой причинен ущерб. Например, часто публикации в СМИ или соцсетях содержат ложную информацию, которая приносит репутационный (нематериальный) ущерб. В данном случае субъектами взыскания морального вреда могут выступать как юридическое лицо, так и гражданин. Юридическое лицо вправе обратиться в суд с иском о компенсации за причиненный ущерб, равно как и гражданин. Таким образом, исходя из правовой природы причиненного вреда (материального или нематериального), возникает и право субъекта на компенсацию морального вреда.

В целом, лицо вправе обратиться за взысканием морального вреда в двух аспектах: когда нарушены его личные неимущественные права либо когда причинен материальный ущерб, в том числе его здоровью.

Также важно отметить, что под моральным вредом понимается душевное и психологическое страдание человека, что, естественно, предполагает такой субъект как физическое лицо, а не юридическое. Поэтому, на наш взгляд, законодатель вправе расширить понятие морального вреда, если резюмирует, что под «страданием» юридического лица понимается невозможность осуществлять деятельность или пользоваться имуществом в течение определенного периода. Таким образом, был бы соблюден главный принцип равенства прав сторон и субъектов при судебной защите.

Ограничение понятия «морального вреда» в пользу физических лиц, как вреда связанного с физическим или моральным страданием физического лица, создает неравенство в применении способов защиты, когда идет речь о взыскании морального вреда юридическим лицом. Компания, являясь, с одной стороны, неодушевленным субъектом, тем не менее, может в лице ее собственников испытывать некоторые моральные страдания из-за невозможности реализации поставленных в уставе компании целей и невыполнения задач в срок, при этом характер страданий не будет связан с репутационными рисками. В данном случае принято говорить об упущенной выгоде для юридического лица. Однако, с этим также можно не согласиться, ведь доказать получение материальной выгоды возможно только при наличии определенных доказательств, а моральный аспект здесь нивелируется.

Получается, что компания не может «страдать» по причине потери имущества или денег, хотя на прак- 
тике все понимают, что при любых финансовых потерях компания в лице ее руководителя или учредителей может испытывать переживания и страдания.

Важным признаком морального вреда является его финансовая основа, так как возмещение производится исключительно в денежном эквиваленте. При этом, чтобы рассчитать сумму компенсации морального вреда, необходимо учитывать ряд условий: длительность причинения материального вреда, тяжесть причинений, которая может выражаться в потере здоровья гражданина или размере материального ущерба (потеря имущества, утрата его функции, уничтожение и порча). Также при определении размера денежной компенсации важен субъект и его психическое отношение (субъективная сторона) к посягательству или лишению прав. В частности, суд будет учитывать умысел или неосторожность действий причинителя морального вреда, его возраст, материальное, а также семейное положение. Об этом свидетельствует часть 2 статьи 1101 ГК РФ.

В октябре 2020 года в Совете Федерации за круглым столом обсуждался актуальный вопрос о урегулировании порядка расчета сумм компенсаций при исчислении размера морального вреда. Финансовый университет при Правительстве РФ произвел исследование среди респондентов по вопросу определения достойной суммы компенсации размера морального вреда. Примечательно, что граждане РФ высоко оценили суммы причинения вреда здоровью, в среднем определив ее размер, близкий к 18 млн. рублей. Данные факты свидетельствуют о неурегулированности правового поля по исследуемой проблеме, а значит, ситуация порождает спорность начислений сумм компенсаций морального вреда, исходя из отсутствия правил или порядка расчета. В частности, судом может быть взыскана моральная компенсация в размере от 5000 рублей до 1000000 рублей, но при этом логика расчета остается темой для споров и дискуссий юристов [4].

В целом, о размере компенсации морального вреда говорит статья 1101 Гражданского Кодекса РФ. В частности, определение ее размера возлагается на суд как на орган, способный произвести справедливый расчет суммы с учетом разумности и справедливости. Однако, такое утверждение не соответствует реальному положению дел в судебной практике. Как правило, судьи не являются специалистами в финансовых вопро- сах, а полагаются на расчеты привлеченных к участию в деле экспертов. Так как привлекать эксперта при определении суммы морального вреда при разрешении спора суд не находит причин, то, как правило, руководствуется судебной практикой вышестоящих судов.

В целом, можно отметить, что размер компенсации будет существенным, если происходит смерть близкого лица (при врачебной ошибке или в результате ДТП) [6]. В этом случае речь идет о взыскании с виновника миллиона и более рублей, но в стандартных, бытовых ситуациях суды не склонны взыскивать моральный вред свыше 10 тысяч рублей (например, при заливе квартиры или незначительном ДТП).

Также нередки случаи урезания судами размера компенсации морального вреда в два и более раза. Например, по делу № 33-18275/2016 в 2016 суд Московской области понизил сумму компенсации от 500 до 250 тыс. руб., а при взыскании тем же судом по делу № 33-14309/2016 морального вреда, причиненного потерей близкого человека, суд снизил размер компенсации с 3000000 руб. до 800000 руб., что естественно вызывает законный протест. Похожие ситуации могут доходить и до абсурда, когда в 2016 году Верховный Суд РФ при смерти бабушки, погибшей в результате ДТП, признал законной назначенную судом первой инстанции компенсацию морального вреда в размере 100-200 тысяч руб. вместо двух миллионов, заявленных родственниками [3].

Что касается высшей судебной практики, то она также слабо сформирована, исходя из того, что суды до настоящего времени руководствуются Постановлением Пленума ВС РФ № 10 от 1994 года с изменением на 2007 г. [1], который определил главным основанием для начисления сумм компенсации обязательное наличие вины нарушителя прав, и предложил судам при исчислении сумм компенсаций морального вреда использовать методику или порядок, которую утвердит соответствующий закон, принятый касаемо определенных правовых отношений. Таким образом, ВС РФ снял с себя ответственность по установлению рекомендательного порядка расчета и размера компенсации морального вреда, указав на необходимость принятия соответствующих правовых актов на соответствующем законодательном уровне.

\section{ЛИТЕРАТУРА:}

1. Постановление Пленума Верховного Суда РФ от 20.12.1994 N10 (ред. от 06.02.2007) «Некоторые вопросы применения законодательства о компенсации морального вреда» //URL: http://www.consultant.ru/document/cons_doc_LAW_5677/

2. Публикации Верховного Суда PФ // URL: http://www.supcourt.ru/press_center/mass_media/28609/ 
3. Добрикова Е. Аналитическая статья на сайте garant.ru“Компенсация морального вреда: тенденции российской судебной практики” 2016 // URL: http:// www.garant.ru/article/864733/

4. Информационно-аналитическая статья на сайте Pravo.ru «0жидания и реальность: компенсация морального вреда в российских судах», 2019 // URL: https://pravo.ru/story/216353/

5. Хлюстов П. Аналитическая обзорная статья на сайте garant.ru «Вправе ли юридическое лицо требовать компенсации морального (репутационного) вреда?» // URL: http://www.garant.ru/ia/opinion/author/hlyustov/702882/

6. Черкунова А.В. Методики расчета компенсации морального вреда. НГУ // URL: https://cyberleninka.ru/article/n/metodiki-rascheta-kompensatsiimoralnogo-vreda/viewer

(с Гудков Анатолий Иванович ( gudkovaniv@yandex.ru),

Красильщиков Анатолий Владимирович ( krasilschikov@inbox.ru), Мищенко Вячеслав Иванович ( vyacheslav-mischenko@mail.ru ). Журнал «Современная наука: актуальные проблемы теории и практики»

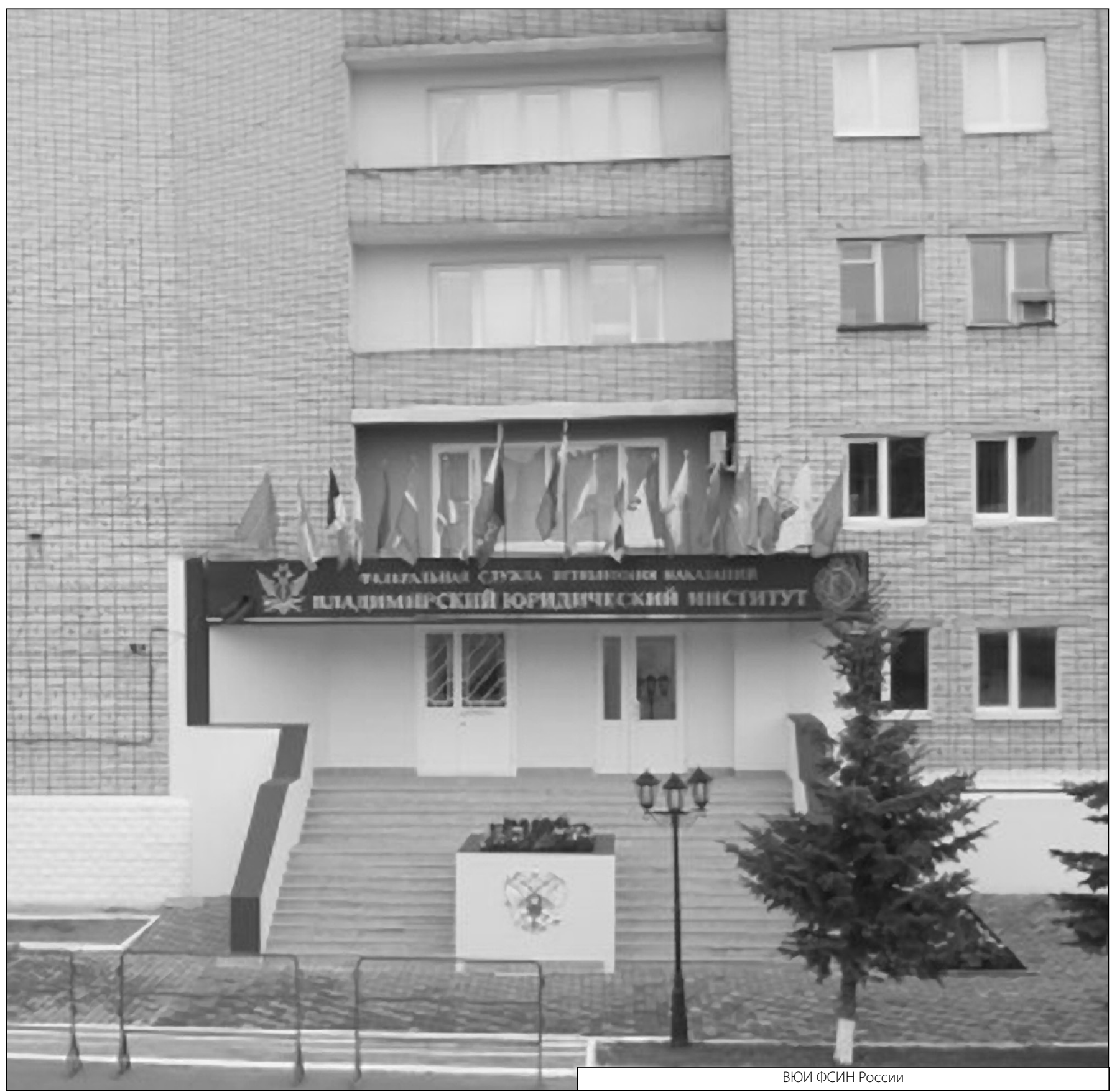

